\title{
Effect of electrochemotherapy on human herpesvirus 8 kinetics in classic Kaposi sarcoma
}

Noemy Starita', Gianluca Di Monta², Andrea Cerasuolo', Ugo Marone², Anna Maria Anniciello³, Gerardo Botti ${ }^{3}$, Luigi Buonaguro ${ }^{1}$, Franco M. Buonaguro ${ }^{1 *}$ and Maria Lina Tornesello ${ }^{1}$

\begin{abstract}
Background: Electrochemotherapy (ECT) has shown to be an effective treatment for cutaneous and subcutaneous Kaposi sarcoma (KS) lesions. However, no study has investigated the impact of ECT treatment on the kinetics of human herpesvirus type $8(\mathrm{HHV} 8)$, which is considered the necessary causal agent of KS. We aimed to evaluate HHV8 viral load and expression levels in patients affected by classic KS who received one or more ECT treatments and have been followed semi annually for up to four years.

Methods: A total of 27 classic KS patients were enrolled in this study. Tumour biopsies and blood samples were obtained before ECT treatment. Additional blood samples were collected at six month intervals for 12-48 months. HHV8 viral load and expression profiles of latent (ORF72 and ORF73) and lytic (K2, K8, K8.1, K10/K10.1, K10.5/K10.6 and ORF16) genes were assessed in all samples by real-time PCR. HHV8 ORF26 and K1 regions were amplified and subjected to direct nucleotide sequencing followed by phylogenetic analysis for variant identification.

Results: All KS biopsies and 46.4\% of peripheral blood mononuclear cells (PBMCs) collected before ECT treatment were positive for HHV8 DNA. Viral load ranged from 0.02 to 2.3 copies per cell in KS lesions and $3.0 \times 10^{-7}$ to $6.9 \times 10$ ${ }^{-4}$ copies per cell in PBMCs. Overall, latent ORF72 and ORF73 as well as lytic K2, K8 and K10/K10.1 were expressed in all KS biopsies. ORF16 mRNA was detected in 71.4\% and both K8.1 and K10.5/K10.6 mRNAs in 57.1\% of KS samples. The ORF72, ORF73 and K2 transcripts were amplified in 37.5\%, 25\% and 25\% of PBMCs collected before ECT, respectively. After the first ECT session, complete response was achieved in 20 out of 27 (74.1\%) patients and HHV8 DNA was detected in four out of 27 (14.8\%) PBMC samples at six month follow up. Phylogenetic analysis of ORF26 amplimers showed that most viral variants belonged to A/C (82.3\%), and few to C2 (5.9\%) or C3 (11.8\%) subtype. The K1NR1 variants fell into A (33.3\%) and C (66.7\%) HHV8 clade. No correlation was found between HHV8 subtypes and ECT complete response.
\end{abstract}

Conclusions: ECT therapy has a significant effect on HHV8 kinetics in patients with classic KS. The complete remission of patients was accompanied by clearance of circulating virus.

Keywords: HHV8, Kaposi sarcoma, Electrochemotherapy, Viral load, ORF26, K1

\footnotetext{
*Correspondence: irccsvir@unina.it; fm.buonaguro@istitutotumori.na.it

1 Molecular Biology and Viral Oncology Unit, Istituto Nazionale Tumori IRCCS

"Fond. G. Pascale", 80131 Naples, Italy

Full list of author information is available at the end of the article
} International License (http://creativecommons.org/licenses/by/4.0/), which permits unrestricted use, distribution, and reproduction in any medium, provided you give appropriate credit to the original author(s) and the source, provide a link to the Creative Commons license, and indicate if changes were made. The Creative Commons Public Domain Dedication waiver (http://creativecommons.org/publicdomain/zero/1.0/) applies to the data made available in this article, unless otherwise stated. 


\section{Background}

Kaposi sarcoma (KS) is a locally aggressive vascular tumour generally presenting with cutaneous multiple patches, plaques or nodules [1]. Epidemiological and clinical forms of KS comprise: 1) the classic or sporadic $\mathrm{KS}$, mainly developing in elderly men of Mediterranean and Eastern European origin; 2) the African or endemic $\mathrm{KS}$; 3) the iatrogenic or immunosuppression-associated $\mathrm{KS}$; and 4) the epidemic or human immunodeficiency virus (HIV)/acquired immunodeficiency syndrome (AIDS)-related KS [2, 3].

The frequency of KS has dramatically increased in Europe and United States during AIDS epidemic and remains one of the most frequent tumours among HIV positive patients [4]. The incidence of classic KS has a marked geographical variation between and within European regions with the highest incidence in southern Europe (ASR 0.8/ 100,000), where it shows a bimodal distribution with peaks in the range of 35-39 years and over 65 [5].

Classic KS is characterized by cutaneous lesions distributed mainly on the lower extremities and trunk and often associated with venous stasis, lymphedema or hyperkeratosis [6, 7]. Different therapeutic options are available depending on disease stage such as lesion excision, laser treatment, cryosurgery, radiotherapy and intra-lesion injection of cytotoxic drugs $[8,9]$. More recently electrochemotherapy (ECT) has shown to be an effective local treatment for KS lesions [10]. ECT is a technique combining the high intensity electric pulses with the administration of non permeant or poorly permeant chemotherapeutic agents, such as bleomycin or cisplatin, to facilitate drug delivery into the tumour cells $[11,12]$. ECT has shown to be very effective for the local treatment of cutaneous metastatic nodules and primary skin tumours including cutaneous $\operatorname{KS}[10,13,14]$.

Human herpesvirus type 8 (HHV8) is recognized as the etiological agent of all forms of $\mathrm{KS}$ and two lymph proliferative disorders, multicentric Castleman disease and primary effusion lymphoma (PEL) [15-19]. The infection is predominant in men (male to female ratio 1015:1) and increases with age suggesting that transmission occurs throughout the whole life [20].

HHV8 infects "spindle" shaped cells, endothelial and epithelial cells as well as B lymphocytes, monocytes and CD34+ stem cells [21-23]. HHV8 encodes several oncogenic viral homologues inducing host cell proliferation, immune evasion and angiogenesis [24]. The viral life cycle comprises the latent and lytic viral programs [25]. The HHV8 genome is maintained in the host cells as an episome and during the latent stage few viral genes are expressed in spindle cells, particularly ORF71 (v-FLIP), ORF72 (v-cyclin) and ORF73 (LANA-1), K12 (kaposin $\mathrm{A}, \mathrm{B}$ and $\mathrm{C}$ ), K1 (VIP) and several miRNA encoding genes [26]. The virus undergoes lytic replication in a limited fraction of latently infected cells and expresses many proteins which through autocrine and paracrine mechanisms directly or indirectly cause alteration of several pathways in the surrounding spindle cells [27].

Several studies have evaluated the association between HHV8 viral load in peripheral blood and KS progression in HIV-infected patients [28, 29]. The aim of this study was to evaluate the effect of ECT on HHV8 viral load and the role of HHV8 latent (ORF72 and ORF73) and lytic (K2, K8, K8.1, K10/ $\mathrm{K} 10.1, \mathrm{~K} 10.5 / \mathrm{K} 10.6$ and ORF16) gene expression in tumour biopsies and peripheral blood mononuclear cells (PBMCs) from patients affected by classic KS with different response to ECT.

\section{Methods}

Patients and samples

This prospective, single-centre study included 27 consecutive patients diagnosed with classic KS lesions on the inferior limbs (24 males and 3 females) that were treated by ECT at the Istituto Nazionale Tumori "Fondazione G. Pascale" of Naples from February 2009 to November 2013. All KS patients were classified as stage I or II based on objective criteria according to Brambilla staging system [30]. Each patient was asked to give a written informed consent to participate to the study and was invited to fill an epidemiological questionnaire regarding lifestyle, risk factors and anamnestic data. Demographic features including patient origin, age at onset, gender, as well as clinical characteristics such as localization of lesions, treatment modalities, tumour recurrence at the time of observation were also recorded. All patients underwent concurrent incisional biopsy and blood sampling for histological examination and HHV8 molecular analyses at the time of enrolment. Further blood samples were collected every six months during follow up visits after ECT treatments. Each biopsy was divided in two sections, one processed for pathological examination and the second stored in RNAlater stabilizing solution $\left(\right.$ Ambion ${ }^{\odot}$ ) at $-80{ }^{\circ} \mathrm{C}$. All cases included in the study were negative for $\mathrm{HIV}-1 / 2$ antibodies by macro enzyme immunoassay. All patients underwent tumour staging by lymph node and abdominal ultrasound as well as chest X-ray. This study was approved by the Institutional Scientific Board and by the Ethical Committee of the Istituto Nazionale Tumori "Fond Pascale", and is in accordance with the principles of the Declaration of Helsinki. All patients provided written informed consent.

\section{Electrochemotherapy treatment regimen}

The ECT treatment regimen was previously described [10]. The treatment was repeated in patients who presented multiple lesions, difficult to treat in a single 
session or if a complete response was not achieved at a first ECT application. The aim of the treatment was curative and repeated several times until the disappearance of the treated lesions.

\section{DNA and RNA isolation}

PBMCs were isolated from fresh blood by Ficoll-Hypaque ${ }^{\text {tm }}$ density gradient. The mononuclear cell layer was resuspended in $500 \mu \mathrm{l}$ of RNAlater and stored at $-80{ }^{\circ} \mathrm{C}$. Genomic DNA was extracted from the PBMCs and KS biopsies according to previously described protocol [31]. In particular, all samples were digested with proteinase $\mathrm{K}$ treatment $(150 \mu \mathrm{g} / \mathrm{ml})$ by $2 \mathrm{~h}$ incubation at $56{ }^{\circ} \mathrm{C}$ or $30 \mathrm{~min}$ at $37^{\circ} \mathrm{C}$ for biopsies or PBMCs, respectively, in 50-500 $\mu \mathrm{l}$ of lysis buffer (10 mM Tris- $\mathrm{HCl}, \mathrm{pH}$ 7.6, $5 \mathrm{mM}$ EDTA, $150 \mathrm{mM} \mathrm{NaCl}, 1 \% \mathrm{SDS}$ ), followed by phenolchloroform-isoamyl alcohol (25:24:1) extraction and ethanol precipitation in $0.3 \mathrm{M}$ sodium acetate ( $\mathrm{pH} 4.6)$.

Total RNA was isolated from frozen biopsies and PBMCs using Trizol ${ }^{\mathrm{Tm}}$ Reagent (Invitrogen ${ }^{\mathrm{Tw}}$ ) following the manufacturer's instructions. Briefly, tissues and PBMCs were resuspended in Trizol reagent and tissues were homogenized by TissueLyser (Qiagen $\mathrm{GmbH}$ ). After 15 min centrifugation at $13000 \mathrm{rpm}$, the top phase was collected and total RNA was precipitated with 0.5 volume of isopropyl alcohol $10 \mathrm{~min}$ at room temperature. RNA pellet was washed with $75 \%$ ethanol, resuspended in sterile water and stored at $-80{ }^{\circ} \mathrm{C}$. RNA quality and concentration was analysed with RNA Nano chipassay on Agilent 2100 Bioanalyzer (Agilent Technologies).

\section{HHV8 viral load}

All DNA samples were subjected to HHV8 quantification by real time PCR using primer pairs amplifying a region within the HHV8 ORF26 as previously described [32]. The PCR reactions were performed in a total volume of $25 \mu \mathrm{L}$ containing $12.5 \mu \mathrm{L}$ of iQ SYBR Green Supermix $(100 \mathrm{mM} \mathrm{KCl}, 40 \mathrm{mM}$ Tris-HCl, pH 8.4, $0.4 \mathrm{mM}$ of each $\mathrm{dNTP}$ and 50 units $/ \mathrm{mL}$ iTaq DNA polymerase, $6 \mathrm{mM} \mathrm{MgCl} 2,20 \mathrm{nM}$ SYBR Green I [BioRad Laboratories, Inc]), 5 pmol of each primer, and 100-500 ng of genomic DNA. All experiments were performed in the CFX96 Real Time System (BioRad Laboratories, Inc). Dilution series (10 to $10^{4}$ copies) of genomic DNA extracted from HHV8-infected BCBL-1 cell line (containing 70 copies per cell of HHV8 DNA) were used to construct the standard curve.

\section{HHV8 latent and lytic gene expression}

Total RNA (100 ng) was reverse transcribed into cDNA using iScript ${ }^{\mathrm{tw}} \mathrm{cDNA}$ Synthesis kit (BioRad Laboratories, Inc.) according to manufacturer's instructions. The reaction was performed in $20 \mu \mathrm{l}$ reaction mixture containing $4 \mu \mathrm{l}$ of $5 \times$ iScript Reaction Mix, $1 \mu \mathrm{l}$ of iScript Reverse
Transcriptase and nuclease-free water in a Perkin Elmer thermo cycler (Gene Amp PCR System 2400, Roche Diagnostic System) with the following steps: $5 \mathrm{~min}$ at $25{ }^{\circ} \mathrm{C}, 30 \mathrm{~min}$ at $42{ }^{\circ} \mathrm{C}$ and $5 \mathrm{~min}$ at $85^{\circ} \mathrm{C}$.

A SYBR Green real time PCR method was used to evaluate latent (ORF72 and ORF73) and lytic (K2, K8, K8.1, K10/K10.1, K10.5/K10.6 and ORF16) gene expression in biopsies and PBMCs. Specially, oligoprimers were designed with Beacon Designer software (Premier Biosoft) and used for real time PCR (Table 1). All reactions were performed in the Bio-Rad CFX96 real time PCR Detection System using $1 \mu \mathrm{l}$ of the cDNA (equivalent to $5 \mathrm{ng} \mathrm{RNA}), 12.5 \mu \mathrm{L}$ of iQ SYBR Green supermix (BioRad Laboratories, Inc.), and 5 pmol of each primer in a final volume of $25 \mu \mathrm{L}$. Thermal cycling consisted of a denaturation step at $95^{\circ} \mathrm{C}$ for $3 \mathrm{~min}$, followed by $40 \mathrm{cy}$ cles of $55{ }^{\circ} \mathrm{C}$ annealing for $30 \mathrm{~s}, 72{ }^{\circ} \mathrm{C}$ extension for $30 \mathrm{~s}$ and $95{ }^{\circ} \mathrm{C}$ denaturation for $30 \mathrm{~s}$.

The amplification of IL- $1 \alpha$ was the positive control of reverse transcription. The reaction conditions were the same used for the viral mRNA quantification and the primer sequences are reported in Table 1.

\section{HHV8 ORF26 and K1 amplification and DNA sequencing}

The HHV8 ORF26 region was amplified by seminested PCR using in the outer reaction the oligonucleotide ORF26LR1F1 (5'-GCAGTATCTATCCAAGTA-3') with

Table 1 PCR primer sequences used to amplify HHV8 latent and lytic mRNAs

\begin{tabular}{|c|c|c|c|}
\hline Locus & $\begin{array}{l}\text { Primer } \\
\text { name }\end{array}$ & Sequences $\left(5^{\prime}-3^{\prime}\right)$ & $\begin{array}{l}\text { cDNA } \\
\text { Amplicon } \\
\text { (bp) }\end{array}$ \\
\hline \multicolumn{4}{|l|}{ Human } \\
\hline$\|-1 a$ & $\begin{array}{l}\text { DM151 } \\
\text { DM152 }\end{array}$ & $\begin{array}{l}\text { GTCTCTGAATCAGAAATCCTTCTATC } \\
\text { CATGTCAAATTTCACTGCTTCATCC }\end{array}$ & 421 \\
\hline \multicolumn{4}{|c|}{ HHV8 latent } \\
\hline ORF72 & $\begin{array}{l}\text { ORF72A } \\
\text { ORF72B }\end{array}$ & $\begin{array}{l}\text { CCGCGCTTITAACTTCTGACTCT } \\
\text { GCTGATAATAGAGGCGGGCAATGA }\end{array}$ & 507 \\
\hline ORF73 & $\begin{array}{l}\text { ORF73A } \\
\text { ORF73B }\end{array}$ & $\begin{array}{l}\text { ACTATGGAAGATTGTAGG } \\
\text { TATATGTGTATTGTCAGAAC }\end{array}$ & 106 \\
\hline \multicolumn{4}{|l|}{ HHV8 lytic } \\
\hline K2 & $\begin{array}{l}\text { ORFK2F } \\
\text { ORFK2R }\end{array}$ & $\begin{array}{l}\text { ATTGAGTCTCTGAATGAG } \\
\text { TTCAAGTTGTGGTCTATC }\end{array}$ & 155 \\
\hline K8 & $\begin{array}{l}\text { ORFK8F } \\
\text { ORFK8R }\end{array}$ & $\begin{array}{l}\text { AAAGCATACACAAGACAG } \\
\text { AAATAATCTGTTCCTTATGTG }\end{array}$ & 100 \\
\hline K8.1 & $\begin{array}{l}\text { ORFK8.1F } \\
\text { ORFK8.1R }\end{array}$ & $\begin{array}{l}\text { CCGATGCCTTAATATCAG } \\
\text { TTCCTCTAGTCGTTGTAG }\end{array}$ & 155 \\
\hline $\begin{array}{l}\mathrm{K} 10.5 / \\
\mathrm{K} 10.6\end{array}$ & $\begin{array}{l}\text { VIRF3F } \\
\text { VIRF3R }\end{array}$ & $\begin{array}{l}\text { GAGTITCACCCACAAATG } \\
\text { CAGGACTCACCTACACAG }\end{array}$ & 107 \\
\hline K10/K10.1 & $\begin{array}{l}\text { VIRF4F } \\
\text { VIRF4R }\end{array}$ & $\begin{array}{l}\text { TGTTCAGTCGTTATATCA } \\
\text { TATTCAGTGTCTGTTGTC }\end{array}$ & 182 \\
\hline ORF16 & $\begin{array}{l}\text { ORF16F } \\
\text { ORF16R }\end{array}$ & $\begin{array}{l}\text { TGGCTATACTGACCTITG } \\
\text { GCTTCATACGCATATACAG }\end{array}$ & $78^{\circ} \mathrm{C}$ \\
\hline
\end{tabular}


ORF26LR1R1 (5'-GGAACCAAGGCTGAT-3') and in the inner reaction the ORF26LR1F1 with ORF26LR2R2 (5'ACAGATCGTCAAGCA-3'). The HHV8 K1 region was amplified by seminested PCR using K1LR1F1 (5'-ATCAA GATGTTCCTGTAT-3') and K1LR1R1 (5'-TATAGTATT TAGTTTGTGACA-3') in the outer reaction and K1LR1F1 and K1LR2R2 (5'-CATTATTTCCAGAGGTAG-3') in the inner reaction yielding an amplimer of 250 bp encompassing the hypervariable region VR1 (aa 54-93). The outer PCR amplification reactions were performed in $50 \mu \mathrm{l}$ reaction mixture containing $300 \mathrm{ng}$ of target DNA, 5 pmol of each primer, $2.5 \mathrm{mM} \mathrm{MgCl}_{2}, 50 \mathrm{nM}$ of each dNTP and $5 \mu \mathrm{l}$ Hot Master buffer and 2.5 U of Hot Master Taq DNA Polymerase (5 Prime GmbH, Hamburg, Germany) while the inner PCR amplifications were performed in $50 \mu \mathrm{l}$ reaction mixture containing $5 \mu \mathrm{l}$ of outer reaction. All samples were amplified in the Agilent Technologies Sure Cycler 8800 thermal cycler with the following steps: an initial 2 min denaturation at $94{ }^{\circ} \mathrm{C}$, followed by 45 amplification cycles for ORF-26 and 38 cycles for ORF-K1 of $55^{\circ} \mathrm{C}$ and $52{ }^{\circ} \mathrm{C}$ respectively for $45 \mathrm{~s}, 68{ }^{\circ} \mathrm{C}$ for $1 \mathrm{~min}, 94{ }^{\circ} \mathrm{C}$ for $15 \mathrm{~s}$ and a 5 min final elongation at $68{ }^{\circ} \mathrm{C}$. Reaction mixture containing genomic DNA, extracted from NIH 3 T3 murine cell line, was used as negative control and included in every set of 5 clinical specimens.

All HHV8 amplimers were subjected to bidirectional direct sequencing analysis by Eurofins Genomics Srl. Nucleotide sequences were edited with Chromas Lite 2.01 (http:// www.technelysium.com.au/chromas.html) and converted to FASTA format.

\section{Phylogenetic analysis}

Multiple alignments of HHV8 nucleotide sequences from the present study and reference strains reported in the GenBank were performed with clustal W tool of MegAlign program of the Lasergene software (DNASTAR Inc., V7.0.0). All reference sequences were downloaded from the National Centre for Biotechnology Information (https:/www.ncbi.nlm.nih.gov/ nuccore/?term=HHV-8). Reference sequences for each HHV8 ORF26 subtype were DQ984689.1 (BCBLR, A/C), DQ984768.1 (HKS15, R), DQ984785.1 (431 K, B1), DQ984789.1 (021 K, B2), and DQ984759.1 (HKS21, J); whereas reference sequences for each HHV8 K1 subtype were AF133038 (BCBL-R, A1), AF133039 (BCBLB, A4), JN800486.1 (QLD-KS-8, A), AF151688.1 (US3/ ts55, A), JN800487.1 (QLD-KS-9, A), AF130284.1 (Ife5, A), KF781665.1 (1ZA, A), GU097427.1 (KE-231, A),; AF133041 (ARM72, C1), AF133042 (BC2, C3), FJ866517.1 (TYKS12, C), DQ394064.1 (I10, C), DQ394068.1 (N1, C), DQ394038.1 (D4.2, C) and DQ394054.1 (D18, C).

Phylogenetic trees were constructed transforming the aligned sequence data into a distance matrix by the Kimura's two parameter model (Kimura, 1980), followed by the neighbor-joining bootstrap analysis [33], which was executed with the MEGA software (version 6.0) [34]. Boot strapping, with 1000 replicates confirmed the robustness of the three major branches with bootstrap values above $90 \%$.

\section{Statistical analysis}

The statistical analysis was performed using Graph Pad Prism Software version 6.00. Two-tailed Fisher's exact test were used for comparison of categorical data. U Mann-Whitney test were used to evaluate differences in viral load. Differences were considered to be statistically significant when $P$ values were less than 0.05 .

\section{Results}

This study included a total of 27 patients (24 males and 3 females) affected by classic KS, with a median age at the diagnosis of 74 years (range 43-88 years of age) (Table 2). The majority of patients $(74.1 \%)$ were above 65 years while $25.9 \%$ were below 65 years of age. All patients received single or multiple ECT treatments as previously described [10], and after 24 months a clinical response was obtained in all of them according to RECIST guidelines. In particular, a complete response was observed in 20 out of 27 patients $(74.1 \%)$ after a single ECT session, in three patients (11.1\%) after two treatments and four patients (14.9\%) after three to six ECT applications. The mean interval between two-consecutive treatments was 145 days. The clinical response to ECT was evaluated four weeks after ECT treatment and monitored every three months during a follow-up period ranging between 24 and 68 months.

KS biopsies were available from 16 patients. PBMC samples collected at the time of enrolment $\left(\mathrm{T}_{0}\right)$, after approximately 6 months $\left(\mathrm{T}_{1}\right)$ and 12 months $\left(\mathrm{T}_{2}\right)$ after ECT therapy were available for 27, 20 and 9 patients, respectively. HHV8 sequences have been identified in $100 \%$ of KS biopsies, in 13 out of 27 (48.1\%) PBMC samples at $\mathrm{T}_{0}$, in 4 out of $20(20 \%)$ at $\mathrm{T}_{1}$ and in 2 out of 9 $(22 \%)$ at $\mathrm{T}_{2}$. (Table 3). HHV8 viral load ranged from 1 to 81 copies per cell in KS biopsies and from $1 \times 10^{-5}$ to $1.6 \times 10^{-1}$ copies per cell in PBMCs at the time of enrolment $\left(\mathrm{T}_{0}\right)$. The differences in viral load between KS lesions and PBMCs were statistically significant $(p=0.006)$, Fig. 1. Following ECT treatments the viral load progressively decreased in PBMCs and became undetectable after 24 months in 11 out of 12 (91.7\%) PBMC samples which were $\mathrm{HHV} 8$ positive at $\mathrm{T}_{0}$, Fig. 2. At the end of the follow-up the single patient who received six ECT treatments reached a complete clinical response but remained positive for HHV8 DNA in PBMCs.

The HHV8 expression profiles showed that latent genes ORF72 and ORF73 as well as lytic genes K2, K8 and K10/K10.1 were expressed in all analysed classic KS lesions. The ORF16 transcript was detected in $71.4 \%$ and both the lytic K8.1 and K10.5/K10.6 in $57.1 \%$ of KS 
Table 2 Patients characteristics, KS lesion sites and number of ECT treatments for each patient

\begin{tabular}{|c|c|c|c|c|c|c|}
\hline ID Patient & Years of diagnosis & Sex & Age & Localization & $\mathrm{N}^{\circ} \mathrm{ECT}$ treatment & Response \\
\hline KS288 & 2009 & M & 45 & Lower limb bilateral & 2 & $C R$ \\
\hline KS290 & 2009 & M & 85 & Left lower limb & 1 & $C R$ \\
\hline KS289 & 2010 & M & 73 & Right foot & 3 & $C R$ \\
\hline KS293 & 2010 & M & 74 & Right lower limb & 2 & $C R$ \\
\hline KS294 & 2010 & M & 79 & Left upper limb & 1 & $C R$ \\
\hline KS295 & 2010 & $\mathrm{~F}$ & 69 & Right lower limb & 1 & $C R$ \\
\hline KS296 & 2011 & M & 77 & Right lower limb & 6 & $C R$ \\
\hline KS298 & 2011 & M & 66 & Right foot & 1 & $C R$ \\
\hline KS299 & 2011 & $\mathrm{~F}$ & 86 & Right foot & 1 & $C R$ \\
\hline KS300 & 2011 & M & 85 & Right foot & 5 & $C R$ \\
\hline KS301 & 2011 & M & 63 & Right foot & 1 & $C R$ \\
\hline KS302 & 2011 & M & 77 & Right lower limb & 1 & $C R$ \\
\hline KS307 & 2012 & M & 72 & Right foot & 1 & $C R$ \\
\hline KS309 & 2012 & M & 88 & Right lower limb & 1 & $C R$ \\
\hline KS310 & 2012 & M & 88 & Right foot & 1 & $C R$ \\
\hline KS315 & 2012 & M & 70 & Left lower limb & 1 & $C R$ \\
\hline KS339 & 2012 & M & 78 & Left lower limb & 1 & $C R$ \\
\hline KS319 & 2013 & $\mathrm{~F}$ & 88 & Right lower limb & 1 & $C R$ \\
\hline KS327 & 2013 & M & 73 & Right foot & 1 & $C R$ \\
\hline KS329 & 2013 & M & 79 & Right lower limb & 1 & $C R$ \\
\hline KS330 & 2013 & M & 83 & Left foot & 1 & $C R$ \\
\hline KS332 & 2013 & M & 46 & Right lower limb & 1 & $C R$ \\
\hline KS333 & 2013 & M & 83 & Right lower limb & 2 & $C R$ \\
\hline KS334 & 2013 & M & 46 & Left foot & 1 & $C R$ \\
\hline KS335 & 2013 & M & 72 & Right foot & 1 & $C R$ \\
\hline KS340 & 2013 & M & 43 & Right foot & 4 & $C R$ \\
\hline KS341 & 2013 & M & 55 & Left foot & 1 & $C R$ \\
\hline
\end{tabular}

$C R$ complete response

tumours. The ORF72, ORF73 and K2 mRNAs were amplified in $37.5 \%, 25 \%$ and $25 \%$ of PBMCs, respectively, collected before ECT treatment. The other HHV8 transcripts were undetectable in all PBMCs. In conclusion, latent and lytic transcripts are frequently expressed in biopsies but occasionally in PBMCs.

The HHV8 ORF26 sequences amplified in $16 \mathrm{KS}$ were subjected to nucleotide sequence and phylogenetic analyses and classified as A/C (13 out of 16, 81.3\%), C2 (1 out of $16,6.3 \%)$ and C3 (2 out of 16, 12.5\%) subtypes, following the nomenclature proposed by Zong et al. [35].

The HHV8 K1 amplimers obtained in 12 tumour samples were subjected to phylogenetic analysis showing a nucleotide divergence among them of $0.7-12.3 \%$ corresponding to a $4.9-43.3 \%$ amino acid divergence in the VR1 (aa 52-92) sequence. Phylogenetic analysis based on the comparison of newly identified K1 sequences with $\mathrm{K} 1$ reference strains available in GenBank showed that four out of 12 (33.3\%) HHV8 K1 variants belonged to subtype A and eight (66.7\%) to subtype C (Figs 3 and 4). Amino acid sequence divergence between subtypes $\mathrm{A}$ and C (7.58\% to $23.31 \%)$ was higher than that observed within subtypes A (3.25 to $9.11 \%$ ) or C (0 to $13.44 \%)$. There was no difference in the response to ECT treatment in patients infected by different $\mathrm{HHV} 8$ variants.

\section{Discussion}

The efficacy of ECT for the treatment of KS was first described by Heller et al. in [36]. To date several reports have confirmed the usefulness of ECT on different neoplastic cutaneous lesions including KS [14]. Di Monta et al. [10] proposed ECT as the "new standard of care" in first line treatment of stage I and II classic KS for the high rate of complete response achieved after a single ECT treatment (73.6\%). The present study represents an extension of the previous patients cohort and confirms 
Table 3 Frequency of HHV8 DNA in classic KS biopsies and persistence of the virus in PBMCs collected from patients at different times following ECT treatment

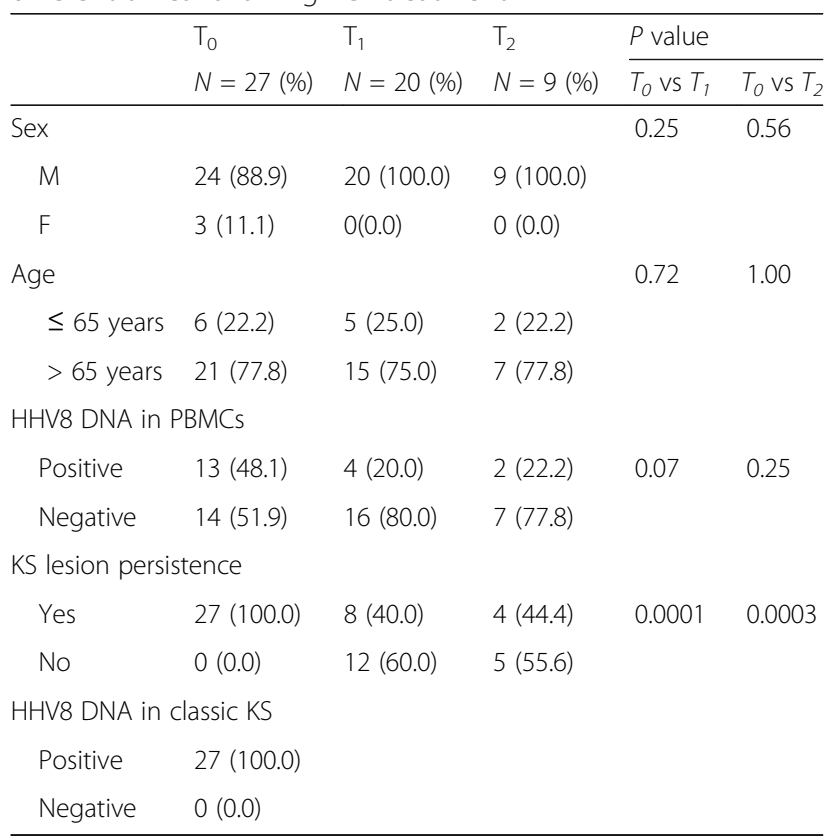

that ECT induces a complete response in above $70 \%$ of KS patients after a single session, regardless of tumour size. Moreover we have evaluated HHV8 kinetics in KS patients treated by ECT and we have observed a viral load decline in those patients with a complete clinical response.

The immunological effect of ECT has been first described in mouse models in which numerous mononuclear cells have shown to accumulate in ECT-treated metastatic lesions [37]. Calvet et al., hypothesized that the residual tumour cells not directly affected by ECT treatment, due to insufficient permeabilization or paucity of bleomycin molecules, are secondarily killed by cytotoxic immune cells activated by immunogenic cell death

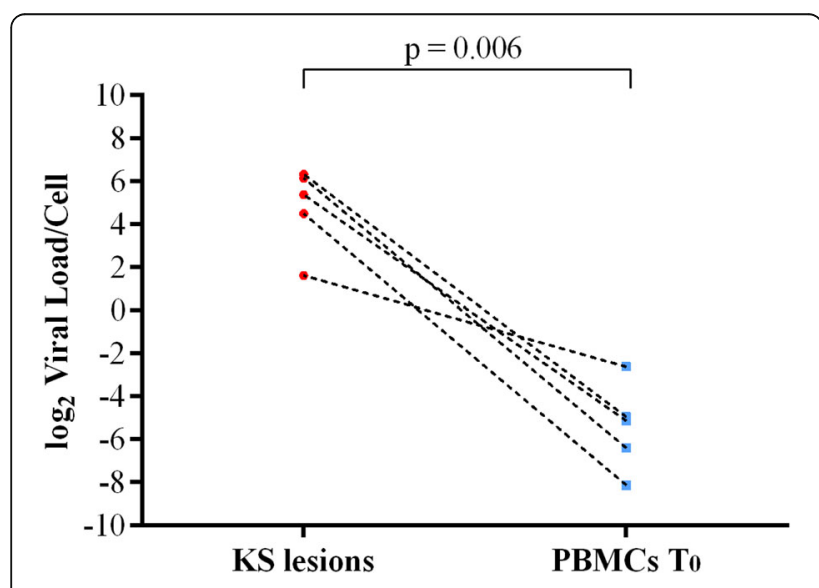

Fig. $1 \mathrm{HHV} 8$ viral load in KS lesions and PBMCs before ECT treatment

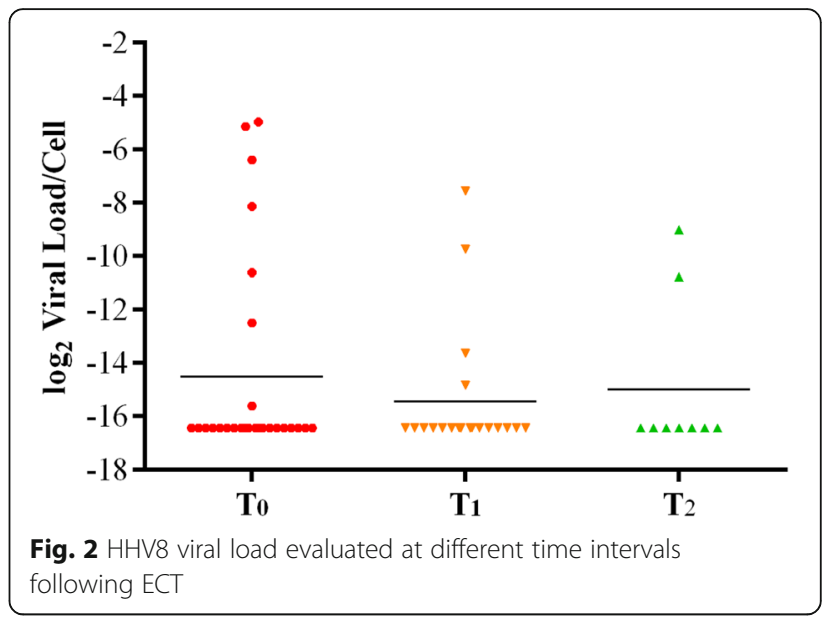

processes in murine colon cancer cells [38]. More recently Di Gennaro et al. analyzed the immune cell profile in biopsies from melanoma patients before and after ECT treatment and reported a relevant local immune response, with decreasing CD4 + FOXP3 + T reg cells and recruitment of CD3 + CD8+ T cells in the treated lesions [39]. It remains unclear whether ECT treatment is sufficient to stimulate a systemic immune response in ECT-treated melanoma patients. Gualdi et al. first reported that ECT has a positive effect on the disappearance of HHV8positive cells at treated sites 2 months after treatment [40]. In our study we observed a progressive decrease of HHV8 viral load in PBMCs of patients presenting a complete clinical response after a single ECT session suggesting a significant effect of ECT on the activation of the immune system against viral antigens. Only a single patient with recurrent KS lesions had invariable viral load after multiple ECT treatments.

The HHV8 genome encodes for several viral IFNregulatory factors (vIRFs) differentially expressed in different cell types. In particular, the K9 (vIRF-1) gene is generally co-expressed with ORF73 (LANA-1) in KS cells, while K10.5/K10.6 (vIRF-3 also termed LANA-2) is mainly transcribed in HHV8-associated lymphomas. Such data suggest that different vIRFs encoding genes are important for HHV8 life cycle and that their expression is regulated by cell specific factors [41]. Hosseinipour et al. analysed the expression profile of HHV8 ORFs in $70 \mathrm{KS}$ biopsies and identified a group of tumours with extensive expression of all viral genes ("extended" viral expression), and a group of KS cases with limited gene transcription restricted to the latency genes ("restricted" viral expression) [42]. Such data suggested the existence of multiple molecular subtypes of KS with different sensitivity to treatments [42]. We have analysed the expression profile of latent genes (ORF72 and ORF73) and lytic genes (K2, K8, K8.1, K10/K10.1, K10.5/K10.6 and ORF16) and found them 


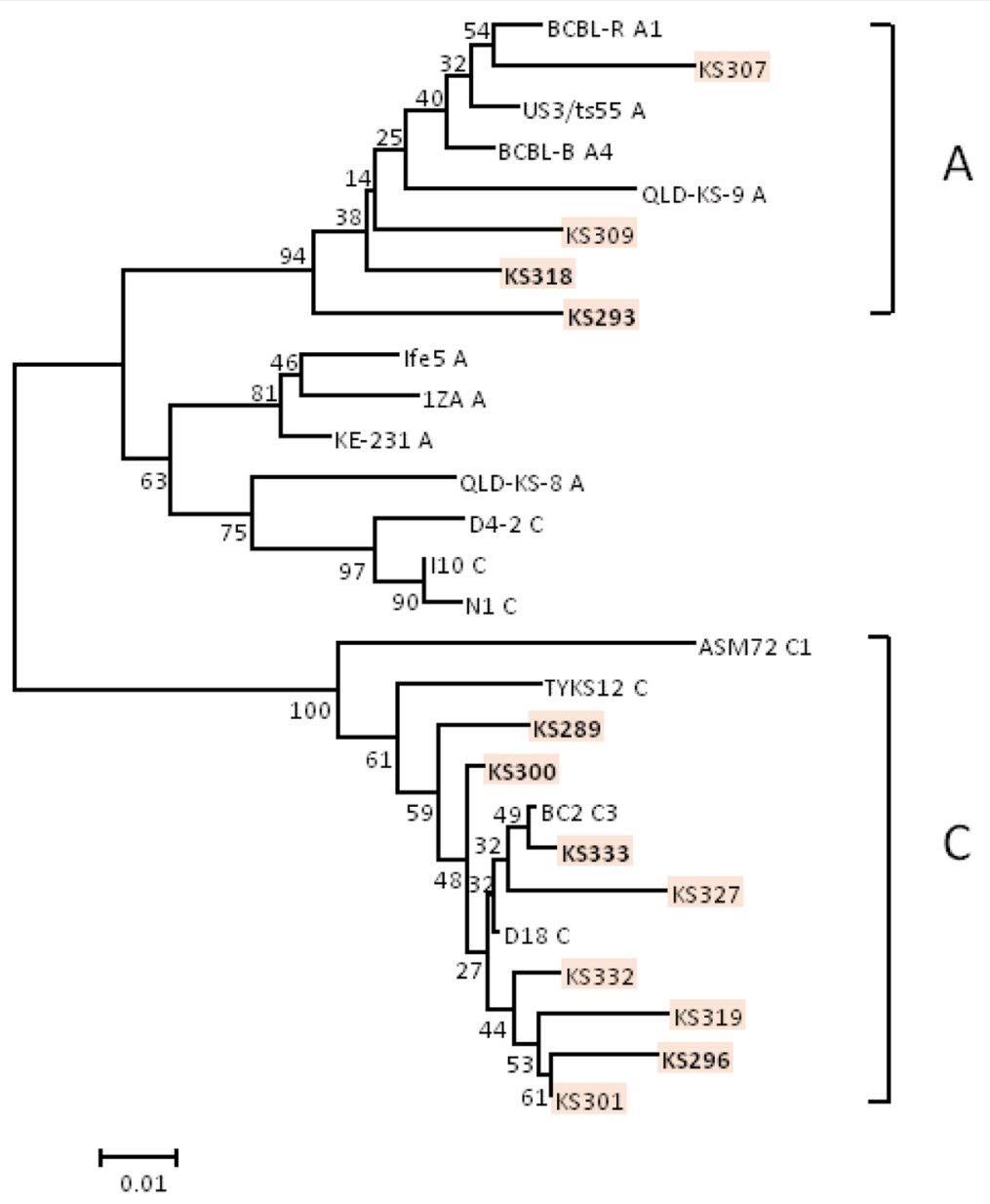

Fig. 3 Phylogenetic tree of HHV8 K1 sequences. Numbers above the branches indicate the bootstrap values (1000 replicates) that are greater than $90 \%$

\begin{tabular}{|c|c|c|c|c|c|c|c|}
\hline & 29 & & 524 & & VR1 & 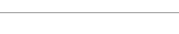 & $\rightarrow \quad 92$ \\
\hline BCBL-R_A1 & GVISTPYKLT & CLSNASLPIS & WYCNNTRLFR & PTETTLFPVT & IACNETCVEQ & SGHRQSIWIT & WHAQPVLQTL \\
\hline BCBL-B_A4 & $\ldots \ldots \ldots$ & $\ldots \ldots \ldots$ & ..D..... & L. .R. . . . & P. $\ldots \ldots$ & $\ldots \ldots \ldots$ & $\ldots \ldots \ldots$ \\
\hline US3/ts55_A & $\ldots \ldots \ldots$ & $\ldots \ldots \ldots$ & $\ldots \ldots \ldots$ & L..R.V... & $\ldots \ldots \ldots$ & $\ldots \ldots \ldots$ & $\ldots \ldots \ldots$ \\
\hline QLD-KS-9_A & . . . . . . & $\ldots \ldots \ldots$ & $\ldots \ldots$ L. & L . . RRV. L . . & $\ldots \ldots \ldots$ & $\ldots \ldots \ldots$ & $\ldots \ldots$ \\
\hline KS293 & 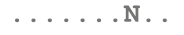 & $\ldots \ldots \ldots$ & $\ldots \ldots \ldots$ & LQ.K. . LG.N & $\ldots \ldots \ldots$ & $\ldots \ldots \ldots$ & $\ldots \ldots \ldots$ \\
\hline KS307 & $\ldots \ldots \ldots$ & $\ldots \ldots \ldots$ & $\ldots \ldots \ldots$ & $\ldots$ NR. . . . N & .D....... & $\ldots \ldots \ldots$ & $\ldots \ldots F$ \\
\hline KS309 & .M...N. & $\ldots \ldots \ldots$ & ........ & L.K... T. & $\ldots \ldots \ldots$ & $\ldots \ldots \ldots$ & $\ldots \ldots \ldots$ \\
\hline KS318 & ...S.T. & $\ldots \ldots \ldots$ & $\ldots \ldots$ L. & L.T...... & L.......... & $\ldots \ldots \ldots$ & $\ldots \ldots$ \\
\hline TYKS12_C & $\ldots \ldots$ т. & .P.T... & $\ldots$. . . . . & L. QQ. VTVA. & LI . . . . . & . . H. I. . &.$Y P \ldots \ldots$ \\
\hline D18_C & $\ldots \ldots$ T. & . P. T. . T. & ...D. . L. & L. QQ.FTV. . & LI...S.G. & ...H.L. . & YP $\ldots \ldots$ \\
\hline ASM72_C1 & . . . & .Р.АT. . T. & ..D.... & L.HD.FTV.N & FI...S. .G. & ……M. & .YG. . . . . \\
\hline BC2_C3 & $\ldots \ldots$ T. & .Р.T. .T. & ...D. . L. & L.QQ.FTV.A & LI. . S. .G. & . . н.г. . & .YP $\ldots \ldots$ \\
\hline KS289 & ...S.T. & .P.T..T. & ...D...L. & L. QQ . FTVH. & LI...S..G. & ...H.L... & ҮT. . . . . \\
\hline KS296 & R..... & . P. T... T. & ....D.... & L.QQ. .TV.N & VI...S..G. & ...H.L... &. YPP $\ldots .$. \\
\hline KS300 & $\ldots \ldots$ T. & . P.T..T. & .... D... & L. QQ. FTVD. & LI...S..G. & ...H.L. . &. YP $\ldots \ldots$ \\
\hline KS301 & R....T. & .P.T..T. & ...D. . L. & L.QQ. .TV.N & LI...S. .G. & . .н.І. . & .YP $\ldots \ldots$ \\
\hline KS319 & R.... T. & . P.T..T. & .... D. L. & L. QQ. . TVSH & LI...S..G. & . . . H. L. &. YP $\ldots \ldots$ \\
\hline KS327 & . . . T. & .Р.T..T. & ...D.L. & L.QQ.ITV. . & LI . .VS. .G. & ‥н.上.. & .YP $\ldots \ldots$ \\
\hline KS332 & R....T. & .Р.T..T. & . . D. .IL. & L.QQ.FTV.N & LI...S. .G. & . .н.І. . & .YP . . . . \\
\hline KS333 & \#.т. & .P.T..T. & ...D... & L.QQ. ITV.A & LI ...S..G. & ...н.І. & .YP $\ldots \ldots$ \\
\hline
\end{tabular}


all expressed in $57.1 \%$ of $\mathrm{KS}$ lesions while the remaining 42.9\% lacked the expression of K8.1 and K10.5/K10.6. No difference was observed in clinical response to ECT between the two groups of tumours.

In recent years, much attention has been paid to the association between different subtypes of HHV8 and KS aggressiveness [43, 44]. In our study we have identified $\mathrm{A} / \mathrm{C}, \mathrm{C} 2$ and $\mathrm{C} 3$ clades on the basis of ORF26 as well as $A$ and $C$ variants on the basis of K1/VR1 nucleotide sequencing analysis. There was no significant difference between HHV8 subtype distribution, viral persistence and clinical response to ECT treatment.

\section{Conclusion}

This study has shown that ECT treatment of patients with classic KS causes a decline of HHV8 virus load in peripheral blood. The complete remission of KS patients treated with ECT is accompanied in the majority of cases by clearance of the virus in the PBMCs. ECT is very effective in the treatment of classic KS independently from HHV8 viral load, viral gene expression and HHV8 variants.

\section{Abbreviations}

ECT: Electrochemotherapy; HHV8: Human herpesvirus type 8; KS: Kaposi sarcoma; PBMCs: Peripheral blood mononuclear cells

\section{Acknowledgements}

Authors would like to thank Clorinda Annunziata and Mario Malinconico for their experimental support.

\section{Funding}

This work was supported by grants from Ministero della Salute (Ricerca Corrente 2016) and from ICSC-World Laboratory (project MCD-2/7).

\section{Availability of data and materials}

Authors can confirm that all relevant data are included in the article and materials are available on request from the authors.

\section{Authors' contributions}

MLT designed the study and edited the final version of the manuscript; NS conducted the sample analysis and drafted the paper; AC and LB contributed to the statistical analyses; AMA and GB performed histopathologic evaluation; GDM and UM provided the clinical samples; FMB supervised the whole project. All authors read and approved the final manuscript.

\section{Competing interests}

The authors declare that they have no competing interests.

\section{Consent for publication}

Not applicable.

\section{Ethics approval and consent to participate}

This study was approved by the Institutional Scientific Board and by the Ethical Committee of the Istituto Nazionale Tumori "Fond Pascale", and is in accordance with the principles of the Declaration of Helsinki. All patients provided written informed consent.

\section{Publisher's Note}

Springer Nature remains neutral with regard to jurisdictional claims in published maps and institutional affiliations.

\section{Author details}

"Molecular Biology and Viral Oncology Unit, Istituto Nazionale Tumori IRCCS "Fond. G. Pascale", 80131 Naples, Italy. ${ }^{2}$ Department of Surgery "Melanoma, Soft Tissues, Head and Neck, Skin Cancers", Istituto Nazionale Tumori IRCCS "Fond. G. Pascale", Naples, Italy. ${ }^{3}$ Department of Pathology, Istituto Nazionale Tumori IRCCS "Fond. G. Pascale", Naples, Italy.

Received: 31 March 2017 Accepted: 11 June 2017

Published online: 19 June 2017

\section{References}

1. Kaposi M. Idiopathisches multiples Pigmentsarkom der Haut. Arch Dermatol Syph. 1872;4:265-73.

2. Schwartz RA, Micali G, Nasca MR, Scuderi L. Kaposi sarcoma: a continuing conundrum. J Am Acad Dermatol. 2008:59:179-206.

3. Ruocco E, Ruocco V, Tornesello ML, Gambardella A, Wolf R, Buonaguro FM. Kaposi's sarcoma: etiology and pathogenesis, inducing factors, causal associations, and treatments: facts and controversies. Clin Dermatol. 2013;31:413-22.

4. Yanik EL, Napravnik S, Cole SR, Achenbach CJ, Gopal S, Olshan A, et al. Incidence and timing of cancer in HIV-infected individuals following initiation of combination antiretroviral therapy. Clin Infect Dis. 2013;57:756-64.

5. Stiller CA, Trama A, Brewster DH, Verne J, Bouchardy C, Navarro C, et al. Descriptive epidemiology of Kaposi sarcoma in Europe. Report from the RARECARE project. Cancer Epidemiol. 2014;38:670-8.

6. Di Lorenzo G, Konstantinopoulos PA, Pantanowitz L, Di Trolio R, De Placido S, Dezube BJ. Management of AIDS-related Kaposi's sarcoma. Lancet Oncol. 2007;8:167-76.

7. Templeton AC, Buxton E, Bianchi A. Cancer in Kyadondo County, Uganda, 1968-70. J Natl Cancer Inst. 1972:48:865-74.

8. Brambilla L, Miedico A, Ferrucci S, Romanelli A, Brambati M, Vinci M, et al. Combination of vinblastine and bleomycin as first line therapy in advanced classic Kaposi's sarcoma. J Eur Acad Dermatol Venereol. 2006;20:1090-4.

9. Casper C. New approaches to the treatment of human herpesvirus 8associated disease. Rev Med Virol. 2008;18:321-9.

10. Di Monta G, Caraco C, Benedetto L, La PS, Marone U, Tornesello ML, et al. Electrochemotherapy as "new standard of care" treatment for cutaneous Kaposi's sarcoma. Eur J Surg Oncol. 2014;40:61-6.

11. Mir LM, Orlowski S, Belehradek J Jr, Paoletti C. Electrochemotherapy potentiation of antitumour effect of bleomycin by local electric pulses. Eur J Cancer. 1991;27:68-72.

12. Testori A, Tosti G, Martinoli C, Spadola G, Cataldo F, Verrecchia F, et al. Electrochemotherapy for cutaneous and subcutaneous tumor lesions: a novel therapeutic approach. Dermatol Ther. 2010;23:651-61.

13. Curatolo P, Quaglino P, Marenco F, Mancini M, Nardo T, Mortera C, et al. Electrochemotherapy in the treatment of Kaposi sarcoma cutaneous lesions: a two-center prospective phase II trial. Ann Surg Oncol. 2012;19:192-8.

14. Kunte C, Letule V, Gehl J, Dahlstroem K, Curatolo P, Rotunno R, et al. Electrochemotherapy in the treatment of metastatic malignant melanoma: a prospective cohort study by InspECT. Br J Dermatol. 2017;10

15. Chang Y, Cesarman E, Pessin MS, Lee F, Culpepper J, Knowles DM, et al. Identification of herpesvirus-like DNA sequences in AIDS-associated Kaposi's sarcoma. Science. 1994;266:1865-9.

16. Buonaguro FM, Tornesello ML, Beth-Giraldo E, Hatzakis A, Mueller N, Downing R, et al. Herpesvirus-like DNA sequences detected in endemic, classic, iatrogenic and epidemic Kaposi's sarcoma (KS) biopsies. Int J Cancer. 1996;65:25-8

17. Soulier J, Grollet L, Oksenhendler E, Cacoub P, Cazals-Hatem D, Babinet P, et al. Kaposi's sarcoma-associated herpesvirus-like DNA sequences in multicentric Castleman's disease. Blood. 1995:86:1276-80.

18. Cesarman E, Chang Y, Moore PS, Said JW, Knowles DM. Kaposi's sarcomaassociated herpesvirus-like DNA sequences in AIDS-related body-cavitybased lymphomas. N Engl J Med. 1995;332:1186-91.

19. Minhas V, Wood C. Epidemiology and transmission of Kaposi's sarcomaassociated herpesvirus. Viruses. 2014;6:4178-94.

20. Vitale F, Briffa DV, Whitby D, Maida I, Grochowska A, Levin A, et al. Kaposi's sarcoma herpes virus and Kaposi's sarcoma in the elderly populations of 3 Mediterranean islands. Int J Cancer. 2001;91:588-91.

21. Wu W, Vieira J, Fiore N, Banerjee P, Sieburg M, Rochford R, et al. KSHV/HHV8 infection of human hematopoietic progenitor (CD34+) cells: persistence 
of infection during hematopoiesis in vitro and in vivo. Blood. 2006;108:14151.

22. Chandran B. Early events in Kaposi's sarcoma-associated herpesvirus infection of target cells. J Virol. 2010;84:2188-99.

23. Corbellino M, Poirel L, Bestetti G, Pizzuto M, Aubin JT, Capra M, et al. Restricted tissue distribution of extralesional Kaposi's sarcoma-associated herpesvirus-like DNA sequences in AIDS patients with Kaposi's sarcoma. AIDS Res Hum Retrovir. 1996;12:651-7.

24. Mesri EA, Cesarman E, Boshoff C. Kaposi's sarcoma and its associated herpesvirus. Nat Rev Cancer. 2010;10:707-19.

25. Sarid R, Flore O, Bohenzky RA, Chang Y, Moore PS. Transcription mapping of the Kaposi's sarcoma-associated herpesvirus (human herpesvirus 8) genome in a body cavity-based lymphoma cell line (BC-1). J Virol. 1998;72:1005-12.

26. Schulz TF, Cesarman E. Kaposi Sarcoma-associated Herpesvirus: mechanisms of oncogenesis. Curr Opin Virol. 2015;14:116-28.

27. Tornesello ML, Buonaguro L, Buonaguro FM. An overview of new biomolecular pathways in pathogen-related cancers. Future Oncol. 2015;11:1625-39.

28. Campbell TB, Borok M, Gwanzura L, MaWhinney S, White IE, Ndemera B, et al. Relationship of human herpesvirus 8 peripheral blood virus load and Kaposi's sarcoma clinical stage. AIDS. 2000;14:2109-16.

29. Pellet C, Chevret S, Blum L, Gauville C, Hurault M, Blanchard G, et al. Virologic and immunologic parameters that predict clinical response of AIDS-associated Kaposi's sarcoma to highly active antiretroviral therapy. J Invest Dermatol. 2001;117:858-63.

30. Brambilla L, Boneschi V, Taglioni M, Ferrucci S. Staging of classic Kaposi's sarcoma: a useful tool for therapeutic choices. Eur J Dermatol. 2003;13:83-6.

31. Tornesello ML, Biryahwaho B, Downing R, Hatzakis A, Alessi E, Cusini M, et al. Human herpesvirus type 8 variants circulating in Europe, Africa and North America in classic, endemic and epidemic Kaposi's sarcoma lesions during pre-AIDS and AIDS era. Virology. 2010;398:280-9.

32. Starita N, Annunziata C, Waddell KM, Buonaguro L, Buonaguro FM, Tornesello ML. Identification of human herpesvirus 8 sequences in conjunctiva intraepithelial neoplasia and squamous cell carcinoma of Ugandan patients. Biomed Res Int. 2015;2015:801353.

33. Saitou N, Nei M. The neighbor-joining method: a new method for reconstructing phylogenetic trees. Mol Biol Evol. 1987;4:406-25.

34. Tamura K, Stecher G, Peterson D, Filipski A, Kumar S. MEGA6: molecular evolutionary genetics analysis version 6.0. Mol Biol Evol. 2013;30:2725-9.

35. Zong JC, Kajumbula H, Boto W, Hayward GS. Evaluation of global clustering patterns and strain variation over an extended ORF26 gene locus from Kaposi's sarcoma herpesvirus. J Clin Virol. 2007;40:19-25.

36. Heller R, Jaroszeski MJ, Reintgen DS, Puleo CA, DeConti RC, Gilbert RA, et al. Treatment of cutaneous and subcutaneous tumors with electrochemotherapy using intralesional bleomycin. Cancer. 1998;83:148-57.

37. Mekid H, Tounekti O, Spatz A, Cemazar M, El Kebir FZ, Mir LM. In vivo evolution of tumour cells after the generation of double-strand DNA breaks. Br J Cancer. 2003;88:1763-71.

38. Calvet CY, Famin D, Andre FM, Mir LM. Electrochemotherapy with bleomycin induces hallmarks of immunogenic cell death in murine colon cancer cells. Oncoimmunology. 2014;3:e28131.

39. Di Gennaro P, Gerlini G, Urso C, Sestini S, Brandani P, Pimpinelli N, et al. CD4 + FOXP3+ T regulatory cells decrease and $\mathrm{CD} 3+\mathrm{CD} 8+\mathrm{T}$ cells recruitment in TILs from melanoma metastases after electrochemotherapy. Clin Exp Metastasis. 2016;33:787-98.

40. Gualdi G, Monari P, Fantini F, Cesinaro AM, Cimitan A. Electrochemotherapyinduced virus disappearance in HHV-8-positive skin nodules of Kaposi sarcoma: first histological and immunohistochemical demonstration of efficacy. J Eur Acad Dermatol Venereol. 2010;24:239-41.

41. Dittmer DP. Transcription profile of Kaposi's sarcoma-associated herpesvirus in primary Kaposi's sarcoma lesions as determined by real-time PCR arrays. Cancer Res. 2003;63:2010-5.

42. Hosseinipour MC, Sweet KM, Xiong J, Namarika D, Mwafongo A, Nyirenda $M$, et al. Viral profiling identifies multiple subtypes of Kaposi's sarcoma. MBio. 2014:5:e01633-14.

43. Mancuso R, Biffi R, Valli M, Bellinvia M, Tourlaki A, Ferrucci S, et al. HHV8 a subtype is associated with rapidly evolving classic Kaposi's sarcoma. J Med Virol. 2008;80:2153-60.

44. Boralevi F, Masquelier B, Denayrolles M, Dupon M, Pellegrin JL, Ragnaud JM, et al. Study of human herpesvirus 8 (HHV-8) variants from Kaposi's sarcoma in France: is HHV-8 subtype A responsible for more agressive tumors? J Infect Dis. 1998;178:1546-7.

\section{Submit your next manuscript to BioMed Central and we will help you at every step:}

- We accept pre-submission inquiries

- Our selector tool helps you to find the most relevant journal

- We provide round the clock customer support

- Convenient online submission

- Thorough peer review

- Inclusion in PubMed and all major indexing services

- Maximum visibility for your research

Submit your manuscript at www.biomedcentral.com/submit 